\title{
The Effect of Calcium-Naloxone Treatment on Blood Calcium, $\beta$-Endorphin, and Acetylcholine in Milk Fever
}

\author{
A. Rizzo, ${ }^{*}$ G. Minoia, ${ }^{*}$ E. Ceci, $†$ R. Manca, ${ }^{*}$ M. Mutinati, ${ }^{*}$ M. Spedicato, ${ }^{*}$ and R. L. Sciorsci ${ }^{* 1}$ \\ *Department of Animal Production, and \\ †Department of Animal Health and Wellbeing, Faculty of Veterinary Medicine of Bari, Valenzano (Bari) 70010, Italy
}

\section{ABSTRACT}

Milk fever is a postpartum syndrome of cows characterized by acute hypocalcemia, which reduces the release of acetylcholine $(\mathrm{ACH})$, inducing flaccid paralysis and recumbency. Our aim was to evaluate the effect of calcium $\left(\mathrm{Ca}^{2+}\right)$ combined with naloxone $(\mathrm{Nx}$, an opioid antagonist; $\mathrm{Ca}^{2+}-\mathrm{Nx}$ ) on plasma concentrations of $\mathrm{ACH}$, B-endorphin (BE), and $\mathrm{Ca}^{2+}$ just before treatment (T0) and at 15, 30, and 90 min after treatment (T15, T30, and T90, respectively). Thirty cows were divided into 3 groups of 10 cows each. In group A1, cows affected by milk fever were treated (i.v.) with a combination of $0.2 \mathrm{~mL} / \mathrm{kg}$ of body weight (BW) of $\mathrm{Ca}^{2+}$ borogluconate $(20 \%)$ and $0.01 \mathrm{mg} / \mathrm{kg}$ of BW of Nx hydrochloride dihydrate. In group A2, cows affected by milk fever were treated (i.v.) with $2 \mathrm{~mL} / \mathrm{kg}$ of $\mathrm{BW}$ of $\mathrm{Ca}^{2+}$ borogluconate (20\%). In group C, healthy cows were treated (i.v.) with a combination of $0.2 \mathrm{~mL} / \mathrm{kg}$ of $\mathrm{BW}$ of $\mathrm{Ca}^{2+}$ borogluconate $(20 \%)$ and $0.01 \mathrm{mg} / \mathrm{kg}$ of $\mathrm{BW}$ of $\mathrm{Nx}$ hydrochloride dihydrate. Cows underwent treatments within $24 \mathrm{~h}$ of calving. Blood samples were collected at T0 and at T15, T30, and T90 for quantitative determination of $\mathrm{ACH}$, $\mathrm{BE}$, and $\mathrm{Ca}^{2+}$. The cows in groups $\mathrm{A} 1$ and $\mathrm{A} 2$ recovered within a mean of $20 \pm 10 \mathrm{~min}$, although 4 cows in group A2 underwent a relapse. Blood $\mathrm{Ca}^{2+}$ concentrations in group C increased slightly at T30 and at T90 (T30: 8.8 $\pm 0.6 \mathrm{mg} / \mathrm{dL}$; T90: $8.7 \pm 0.6 \mathrm{mg} / \mathrm{dL}$ ) after treatment, whereas the response in groups affected by milk fever was similar, even though $\mathrm{Ca}^{2+}$ concentrations showed a sharp increase (A1: $8.9 \pm 0.8 \mathrm{mg} / \mathrm{dL} ; \mathrm{A} 2: 6.0 \pm 0.7 \mathrm{mg} /$ $\mathrm{dL}$ ), particularly at T15 in group A1. Concentrations of $\mathrm{BE}$ showed a similar pattern in groups $\mathrm{A} 1$ and $\mathrm{C}$, with an increase at T15 (A1: $8.2 \pm 1.0 \mathrm{ng} / \mathrm{mL}$; C: $2.7 \pm 0.4$ $\mathrm{ng} / \mathrm{mL}$ ) and a subsequent decrease until T90 (A1: $1.4 \pm$ $0.3 \mathrm{ng} / \mathrm{mL}$; C: $1.4 \pm 0.4 \mathrm{ng} / \mathrm{mL}$ ), whereas BE remained constant throughout in group A2. Concentrations of $\mathrm{ACH}$ in group A1 decreased significantly between T0 and T15, T30, and T90 (T0: $7.2 \pm 1.1 \mathrm{nmol} / \mathrm{L}$; T15:

Received November 6, 2007.

Accepted May 26, 2008.

${ }^{1}$ Corresponding author: r.sciorsci@veterinaria.uniba.it
$4.2 \pm 1.2 \mathrm{nmol} / \mathrm{L}$; T30: $2.9 \pm 0.8 \mathrm{nmol} / \mathrm{L}$; T90: $3.1 \pm 0.3$ $\mathrm{nmol} / \mathrm{L}$ ), whereas in group $\mathrm{A} 2$, it did not change. In group $\mathrm{C}$, concentrations of $\mathrm{ACH}$ decreased at $\mathrm{T} 15$ and increased again at T30 (T15: $1.1 \pm 0.3 \mathrm{nmol} / \mathrm{L}$; T30: 3.2 $\pm 0.7 \mathrm{nmol} / \mathrm{L}$ ). Our results suggest that administration of $\mathrm{Ca}^{2+}-\mathrm{Nx}$, which restored the physiological $\mathrm{Ca}^{2+}$ concentrations, might have an effect on nicotinic receptors by restoring the normal neuromuscular transmission at the motor endplate.

Key words: milk fever, acetylcholine, B-endorphin, calcium-naloxone

\section{INTRODUCTION}

Milk fever is one of the most common metabolic disorders in dairy cattle, with an incidence of 5 to $10 \%$ per lactation. In milk fever, the homeostatic mechanisms fail to maintain normal plasma calcium $\left(\mathrm{Ca}^{2+}\right)$ concentrations (9 to $10 \mathrm{mg} / \mathrm{dL}$; Goff et al., 1995). Plasma $\mathrm{Ca}^{2+}$ concentrations are controlled by the coordinated actions of calcitropic hormones, such as the parathyroid hormone and 1,25-dihydroxyvitamin $\mathrm{D}_{3}$, the concentration of which increases in response to hypocalcemia and acts to augment the pool of plasma $\mathrm{Ca}^{2+}$ (Horst and Reinhardt, 1983). Milk fever is associated with the sudden onset of lactation and usually occurs within 72 h of calving (Sorensen et al., 2002).

At parturition, cows have an increased $\mathrm{Ca}^{2+}$ requirement, and if they are unable to respond quickly to this demand, hypocalcemia develops. In most of the mammalian species, this condition is associated with a progressive increase in endogenous opioid peptides (EOP), which occurs during parturition (Petraglia et al., 1985; Sciorsci et al., 2001). These EOP, particularly B-endorphins $(\boldsymbol{\beta E})$, activate their specific receptors, giving rise to many cellular responses, including blockage of the voltage-gated $\mathrm{Ca}^{2+}$ channels and opening of the $\mathrm{K}^{+}$channels, which act synergistically, thereby inhibiting the release of acetylcholine (ACH) from the presynaptic membrane (Kim et al., 2005). This inhibition impairs normal neuromuscular transmission and muscle contraction (Sciorsci et al., 2000; Minoia and Sciorsci, 2001; Mayerhofer and Fritz, 2002). 
Based on this knowledge, Sciorsci et al. (2001) demonstrated that administration of $\mathrm{Ca}^{2+}$ and naloxone $(\mathbf{N x})$, an opioid antagonist, together $\left(\mathrm{Ca}^{2+}-\mathrm{Nx}\right)$ resulted in a faster and better recovery from milk fever than that achievable from administration of either $\mathrm{Nx}$ or $\mathrm{Ca}^{2+}$ alone. Thus, our aim was to evaluate the effects of $\mathrm{Ca}^{2+}-\mathrm{Nx}$ on plasma concentrations of $\mathrm{ACH}, \mathrm{BE}$, and $\mathrm{Ca}^{2+}$.

\section{MATERIALS AND METHODS}

\section{Experimental Animals}

The study was performed between June 2005 and April 2006 on 30 Friesian cows (5 to 8 yr old). All the cows delivered their calves no more than $24 \mathrm{~h}$ before the treatments, with normal delivery and without placental retention. The animals had a mean BW of 600 $\mathrm{kg}$ (range 560 to $650 \mathrm{~kg}$ ) and were maintained on farms in the south of Italy (Bari, Apulia).The animals were between the third and the fifth lactation, with average milk production ranging from 8,300 to $8,500 \mathrm{~kg}$ per lactation. Cows were restrained in tie stalls and fed hay, concentrate, and minerals, with access to water ad libitum. All cows underwent a clinical examination resulting in the diagnosis of milk fever $(\mathrm{n}=20)$ within 24 $\mathrm{h}$ of calving. The diagnosis was performed by reference to the anamnesis, the evaluation of clinical symptoms (anorexia, recumbency, absence of rumination, tachycardia, tachypnea, and muscular spasms followed by flaccid paralysis) and plasma $\mathrm{Ca}^{2+}$ concentrations $<6$ $\mathrm{mg} / \mathrm{dL}$ (Lindsay and Pethick, 1983). The cows were divided into 3 groups: groups A1 and A2, made up of 10 cows each that were affected by milk fever; and group $\mathrm{C}$, made up of 10 healthy cows. In the first week after parturition, all the cows underwent a daily general health examination to evaluate their clinical status. All the procedures were carried out in accordance with the Italian Legislation on animal care (DL 116/92).

\section{Treatment and Blood Collection}

Groups $\mathrm{A} 1$ and $\mathrm{C}$ received the same treatment, consisting of a single i.v. infusion of $0.2 \mathrm{~mL} / \mathrm{kg}$ of $\mathrm{BW}$ of $\mathrm{Ca}^{2+}$ borogluconate (20\%; Fatro, Ozzano Emilia, Italy) and $0.01 \mathrm{mg} / \mathrm{kg}$ of $\mathrm{BW}$ of $\mathrm{Nx}$ hydrochloride dihydrate (Sigma, Milano, Italy) administered soon after the clinical examination. Group A2 was treated with a single i.v. administration of $2 \mathrm{~mL} / \mathrm{kg}$ of $\mathrm{BW}$ of $\mathrm{Ca}^{2+}$ borogluconate (20\%; Fatro; Sciorsci et al., 2001).

Blood samples were collected before (T0) and at 15 (T15), 30 (T30), and 90 (T90) min after treatments for the analysis of $\mathrm{ACH}, \mathrm{BE}$, and $\mathrm{Ca}^{2+}$ concentrations. All the blood samples were collected by jugular veni- puncture with refrigerated Vacutainer tubes and were maintained at $4^{\circ} \mathrm{C}$ until taken to the laboratory within $2 \mathrm{~h}$.

\section{ACH Determination}

The blood samples for ACH determination were collected in Vacutainer tubes containing lithium-heparin, with the addition of $2.5 \mathrm{mmol}$ of physostigmine (Sigma). They were centrifuged at $1,620 \times \mathrm{g}$ for $10 \mathrm{~min}$ at $4^{\circ} \mathrm{C}$. The plasma was stored at $-20^{\circ} \mathrm{C}$ in Eppendorf tubes (Eppendorf, Milan, Italy) with the addition of 0.25 mmol of physostigmine, until analysis. The analysis was performed by using HPLC-electrospray ionization mass spectrometry, with an 8 mpos dead-end path column (Superchrom, Milan, Italy). The HPLC method was a modified isocratic reversed-phase ion-pairing procedure. The mobile phase was prepared by adding 1 $\mathrm{mL}$ of heptafluorobutyric acid to $980 \mathrm{~mL}$ of water, followed by $20 \mathrm{~mL}$ of methanol. Luna C18 HPLC columns

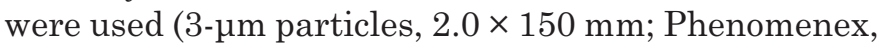
Torrence, CA). The column was eluted isocratically at a flow rate of $0.3 \mathrm{~mL} / \mathrm{min}$ and was maintained at $60^{\circ} \mathrm{C}$. The mass spectrometer was operated either in the selected ion-monitoring mode or in the selected reactionmonitoring mode. The selected reaction-monitoring experiments monitored a collision-induced dissociation transition for each of the compounds. The transition producing the most abundant ion fragments was selected for the analysis $\left(146^{+} / 87^{+}\right.$for ACH). Detection was performed by using a Thermo mass spectrometer (Thermo Finnigan, San Jose, CA) equipped with the manufacturer's heated capillary atmospheric pressure ionization interface operating in the electrospray ionization mode. The method detected $\mathrm{ACH}$ and its primary degradation product, choline, at the 10 -fmol level, with an analysis time of less than $6 \mathrm{~min}$. The intraassay $\mathrm{CV}$ was $<2 \%$.

\section{BE Determination}

The blood samples for BE determination were collected by using Vacutainer tubes containing EDTA and aprotinin (500 kIU; Sigma). The samples were centrifuged at $1,620 \times \mathrm{g}$ for $10 \mathrm{~min}$ at $4^{\circ} \mathrm{C}$ and plasma was stored at $-20^{\circ} \mathrm{C}$ in Eppendorf tubes containing $50 \mathrm{kIU}$ of aprotinin until analysis. B-Endorphin determination was performed by using the Basic Robot Immunoassay Operator 4.54 (Radim, Pomezia, Italy), which relied on an immunoenzymatic method, and a Peninsula kit (Peninsula Laboratories Inc., San Carlos, CA) specific for bovine species (sensitivity 0.03 to $0.06 \mathrm{ng} / \mathrm{mL}$ ). The intraassay $\mathrm{CV}$ was $<5 \%$. 


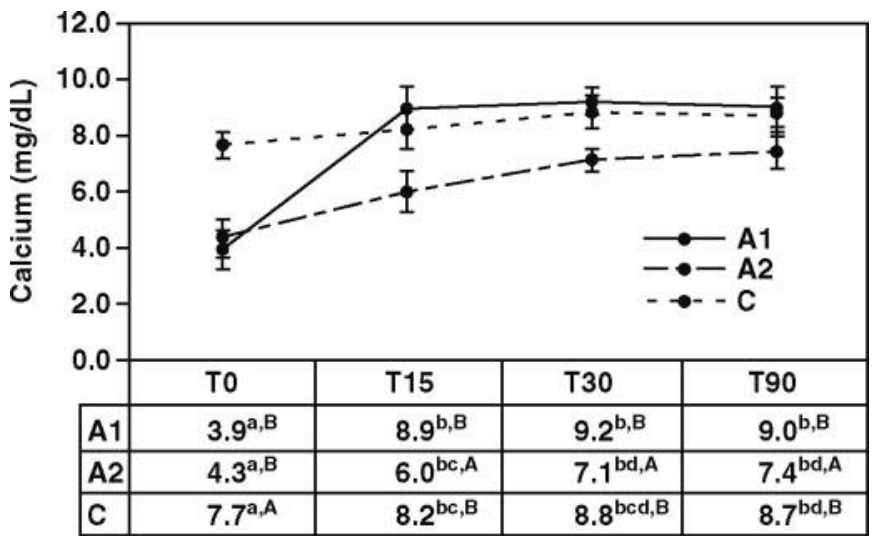

Figure 1. Calcium $\left(\mathrm{Ca}^{2+}\right)$ concentrations $( \pm \mathrm{SD})$ in group $\mathrm{A} 1$ (cows affected by milk fever treated with $\mathrm{Ca}^{2+}$-naloxone), in group A2 (cows affected by milk fever treated with $\mathrm{Ca}^{2+}$ ), and in group $\mathrm{C}$ (healthy cows treated with $\mathrm{Ca}^{2+}$-naloxone) at T0 (before treatment), T15 (15 min after treatment), T30 (30 min after treatment), and T90 (90 min after treatment). Means in rows with lowercase $a, b, c$, and d differ at $P<0.01$. Means in columns with uppercase $\mathrm{A}$ and $\mathrm{B}$ differ at $P<$ 0.001 .

\section{$\mathrm{Ca}^{2+}$ Determination}

Blood samples for $\mathrm{Ca}^{2+}$ determination were collected in serum Vacutainer tubes. The samples were centrifuged at $1,620 \times \mathrm{g}$ for $10 \mathrm{~min}$ at $4^{\circ} \mathrm{C}$. The sera were stored at $-20^{\circ} \mathrm{C}$ in Eppendorf tubes until analysis. Calcium determination was by a colorimetric method

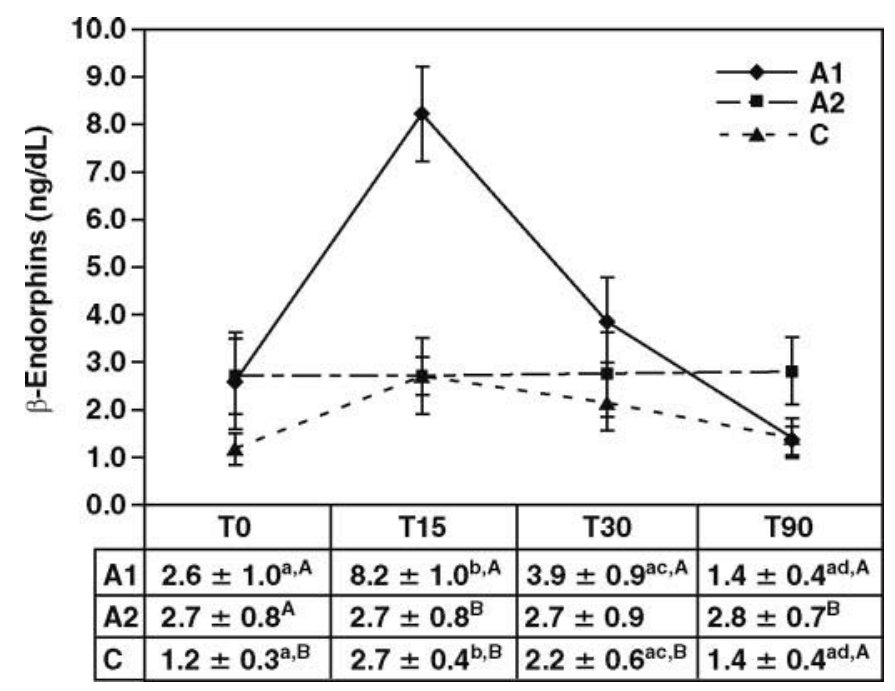

Figure 2. B-Endorphin concentrations $( \pm \mathrm{SD})$ in group A1 (cows affected by milk fever treated with $\mathrm{Ca}^{2+}$-naloxone), in group A2 (cows affected by milk fever treated with $\mathrm{Ca}^{2+}$ ), and in group $\mathrm{C}$ (healthy cows treated with $\mathrm{Ca}^{2+}$-naloxone) at T0 (before treatment), T15 (15 min after treatment), T30 (30 min after treatment) and T90 (90 min after treatment). Means in rows with lowercase a, b, c, and d differ at $P<0.01$. Means in columns with uppercase $\mathrm{A}$ and $\mathrm{B}$ differ at $P<$ 0.001 . with a Seac kit (Radim; sensitivity $0.6 \mathrm{mg} / \mathrm{dL}$ ). The intraassay CV was $<0.81 \%$.

\section{Statistical Analysis}

All values are expressed as mean \pm standard deviation. The 1-sample Kolmogorov-Smirnov test was used to assess the normal (Gaussian) distribution of data. The statistical analysis was then carried out following a nonparametric approach with a 2 -way Friedman nonparametric test. The Kruskal-Wallis test was applied to investigate the differences among the 3 groups. The Bonferroni correction was used to account for multiple comparisons. The statistical significance level was set at $<5 \%$. The statistical tests were performed by SPSS and Matlab software (Mathworks, Torino, Italy).

\section{RESULTS}

Cows in groups A1 and A2 recovered from milk fever within 20 min after treatment (able to stand, restoration of rumination, and displaying a normal heart rate and normal respiration), although 4 cows in group A2 subsequently relapsed. Figures 1, 2, and 3 show the concentrations and the profiles of $\mathrm{ACH}, \mathrm{BE}$, and $\mathrm{Ca}^{2+}$ concentrations in the 3 groups.

Serum $\mathrm{Ca}^{2+}$ in groups $\mathrm{A} 1$ and $\mathrm{C}$ increased from T0 to T15 $(P<0.01)$. It remained constant in A1 (Figure 1 ), whereas it increased at T90 in C cows. In group A2, $\mathrm{Ca}^{2+}$ concentration increased from T0 to T30 $(P<0.01)$, remaining constant from T30 to T90. At T0, mean $\mathrm{Ca}^{2+}$ concentrations were different between groups $\mathrm{A} 1$ and $\mathrm{C}$ and groups $\mathrm{A} 2$ and $\mathrm{C}(P<0.01)$. At all other times, $\mathrm{Ca}^{2+}$ concentrations in group A2 were lower than in groups $\mathrm{A} 1$ and $\mathrm{C}(P<0.01)$.

In groups $\mathrm{A} 1$ and $\mathrm{C}, \mathrm{BE}$ concentrations found at $\mathrm{T} 15$ were greater than those found at T0, T30, and T90 $(P<$ 0.01 ). No significant differences were observed in group A2 among the different times. Group A1 had greater $\mathrm{BE}$ concentrations than group $\mathrm{C}$ at $\mathrm{T} 0$, greater $\mathrm{BE}$ concentrations than groups $\mathrm{A} 2$ and $\mathrm{C}$ at $\mathrm{T} 15$, greater $\mathrm{BE}$ concentration than group $\mathrm{C}$ at $\mathrm{T} 30$, and lower $\mathrm{BE}$ concentration than group A2 at T90, peaking at T15 (Figure 2).

Acetylcholine concentration in group A1 was higher at T0 compared with T15, T30, and T90 $(P<0.01$; Figure 3). In group A2, ACH decreased from T0 to T30. The concentration of $\mathrm{ACH}$ in group $\mathrm{C}$ at $\mathrm{T} 15$ was less than the concentrations found at T0, T30, and T90 ( $P$ $<0.01$ ). The comparisons among the 3 groups clearly showed that at T0, ACH concentrations detected in the groups affected by milk fever were greater than that found in the healthy group. At T15, differences were noted between groups $\mathrm{A} 1$ and $\mathrm{A} 2$ and groups $\mathrm{A} 1$ and $\mathrm{C}$. 
At $\mathrm{T} 30$ and $\mathrm{T} 90, \mathrm{ACH}$ concentration in group A2 was greater than the $\mathrm{ACH}$ concentrations in groups $\mathrm{A} 1$ and C.

\section{DISCUSSION}

The combined $\mathrm{Ca}^{2+}-\mathrm{Nx}$ treatment did not induce side effects in the animals treated. This study demonstrated the effect of this new therapeutic approach on the restoration of blood concentrations of $\mathrm{ACH}, \mathrm{BE}$, and $\mathrm{Ca}^{2+}$ and on the rapid clinical recovery of cows affected by milk fever.

Concentrations of $\mathrm{Ca}^{2+}$ in group $\mathrm{A} 1$ reached the same values as obtained in the healthy group, whereas in group $\mathrm{A} 2, \mathrm{Ca}^{2+}$ concentrations were lower than those found in the other groups. This demonstrated that administration of $\mathrm{Ca}^{2+}-\mathrm{Nx}$ may be a more valuable therapeutic approach than $\mathrm{Ca}^{2+}$ alone for recovery from milk fever. The observed increase of $\mathrm{Ca}^{2+}$ in $\mathrm{A} 1$ may be due to the effect of the administration of exogenous $\mathrm{Ca}^{2+}$ and displacement of $\mathrm{BE}$ from receptors induced by naloxone, with a subsequent restoration of blood $\mathrm{Ca}^{2+}$.

Moreover, naloxone alone increased blood $\mathrm{Ca}^{2+}$ levels (Frago et al., 2007). Lower serum $\mathrm{Ca}^{2+}$ concentrations were found in group A2 than in group A1, notwithstanding a higher infusion rate of $\mathrm{Ca}^{2+}$. This finding can be explained in different ways. Our hypothesis is that EOP, found in greater concentrations in cows affected by milk fever, inhibit the release of the antidiuretic hormone (Grossman et al., 1980), thus impairing renal absorption of $\mathrm{Ca}^{2+}$ and allowing for a greater urine production and $\mathrm{Ca}^{2+}$ elimination.

Furthermore, EOP block $\mathrm{Ca}^{2+}$ channels, impairing its utilization by the cells (Sciorsci et al., 2001). Consequently, more $\mathrm{Ca}^{2+}$ is excreted than is retained by the cells. Moreover, administration of high doses of $\mathrm{Ca}^{2+}$ further contributes to increased urine production (Sansoè and Wong, 2007), and thus renal excretion of $\mathrm{Ca}^{2+}$. Finally, a high infusion rate of $\mathrm{Ca}^{2+}$ within minutes widely inhibits parathyroid hormone secretion, lowering blood $\mathrm{Ca}^{2+}$ concentrations (Fukagawa and Kurokawa, 2002).

Concentrations of $\mathrm{BE}$ were greater in groups $\mathrm{A} 1$ and A2 than in group $\mathrm{C}$ at T0, thus confirming the link between $\mathrm{BE}$ and milk fever suggested by Sciorsci et al. (2001). In group A1, the observed changes reflect a therapeutic effect of naloxone (half-life 15 to $20 \mathrm{~min}$; Panerai, 1998), which antagonizes opioids on their membrane receptors. As a consequence, an increase in blood concentrations of $\mathrm{BE}$ occurred 15 min after the administration of $\mathrm{Ca}^{2+}-\mathrm{Nx}$, whereas the subsequent decrease was probably due to degradation exerted by the plasma proteases or to the fading of the pharmacological effects of naloxone, or both. These changes

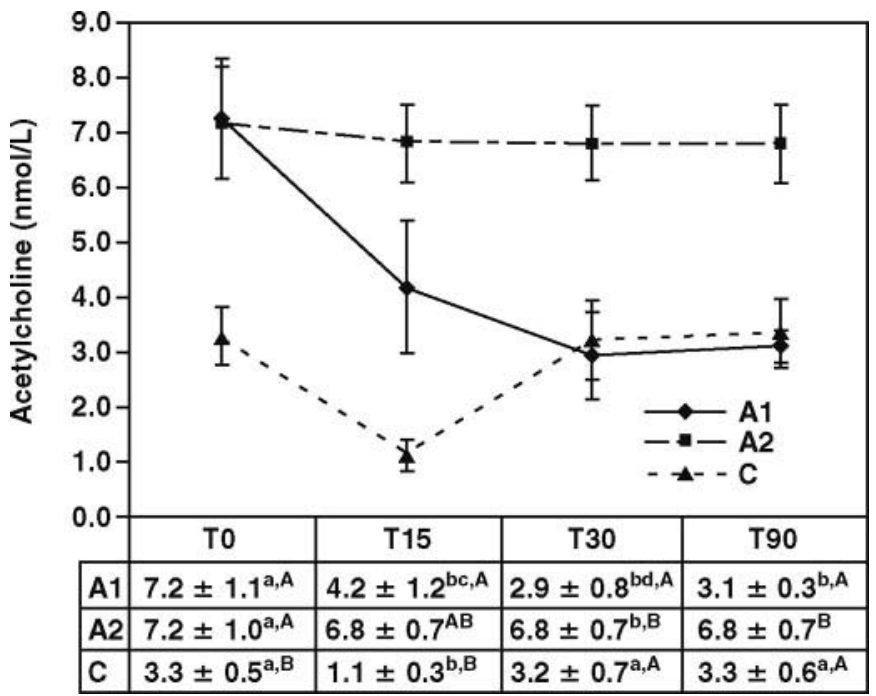

Figure 3. Acetylcholine concentrations $( \pm \mathrm{SD})$ in group $\mathrm{A} 1$ (cows affected by milk fever treated with $\mathrm{Ca}^{2+}$-naloxone), in group $\mathrm{A} 2$ (cows affected by milk fever treated with $\mathrm{Ca}^{2+}$ ), and in group $\mathrm{C}$ (healthy cows treated with $\mathrm{Ca}^{2+}$-naloxone) at T0 (before treatment), T15 (15 min after treatment), T30 (30 min after treatment), and T90 (90 min after treatment). Means in rows with lowercase a, b, c, and d differ at $P<0.01$. Means in columns with uppercase $\mathrm{A}$ and $\mathrm{B}$ differ at $P<$ 0.001 .

did not occur in group $\mathrm{C}$ because $\mathrm{BE}$ concentrations in the healthy group were significantly lower at T0 than BE concentrations in the affected groups. Thus, the increase was not as dramatic as the one observed in group $\mathrm{A} 1$ at $\mathrm{T} 15$.

In group $\mathrm{A} 2$, treatment with $\mathrm{Ca}^{2+}$ alone did not induce any change in concentrations of $B \mathrm{E}$, thus suggesting $\mathrm{BE}$ were not displaced from their receptors. This condition may have been responsible for the relapses that occurred in this group, thus confirming the role of the EOP in the onset of milk fever.

Acetylcholine concentration at T0 was greater in cows affected by milk fever than in healthy cows, suggesting an association among greater concentrations of circulating $\mathrm{ACH}$, low plasma $\mathrm{Ca}^{2+}$, and milk fever. Concentration of $\mathrm{ACH}$ in group $\mathrm{A} 1$ decreased from $\mathrm{T} 0$ to T15 through T90, reaching the values found in group $\mathrm{C}$ at T30, whereas it decreased from T0 to T30 in group A2. This difference highlights the effect of naloxone, which may enhance postsynaptic $\mathrm{Ca}^{2+}$ turnover, inducing the expression of nicotinic receptors (McManaman et al., 1981; Smilowitz et al., 1981). With the greater concentrations of $\mathrm{ACH}$ detected at T0 in the groups affected by milk fever, we hypothesize that ACH could be released from the presynaptic vesicles in the neuromuscular plaque but that postsynaptic receptor responsiveness may be inadequate.

Administration of $\mathrm{Ca}^{2+}-\mathrm{Nx}$, which restores the physiologic $\mathrm{Ca}^{2+}$ concentrations in cows with milk fever, 
might have had an effect on nicotinic receptors, thus decreasing blood concentrations of $\mathrm{ACH}$ and restoring normal neuromuscular transmission, which was clinically manifested by the end of recumbency.

\section{CONCLUSIONS}

The results obtained suggest that in milk fever, the release of ACH may occur, even if it cannot adequately bind to its specific postsynaptic receptors. This confirms the efficacy of the therapeutic protocol consisting of the combination of $\mathrm{Ca}^{2+}$ and $\mathrm{Nx}$. Our study provides the basis for further research to better define the exact role of $\mathrm{BE}$ and $\mathrm{ACH}$ in the pathogenesis of milk fever.

\section{ACKNOWLEDGMENTS}

We dedicate this work to our late lamented, respected senior professor Paolo Minoia. We thank Lara Castellana for statistical support.

\section{REFERENCES}

Frago, F., R. Manzo, J. C. Dalton, M. A. McGuire, and A. Ahmadzadeh 2007. Case study: Naloxone increases serum Ca concentrations after parturition in multiparous Holstein cows. Prof. Anim. Sci. 23:70-72.

Fukagawa, M., and K. Kurokawa. 2002. Calcium homeostasis and imbalance. Nephron 92(Suppl. 1):41-45.

Goff, J. P., T. A. Reinhardt, and R. L. Horst. 1995. Milk fever and dietary cation-anion balance effects on concentration of vitamin D receptor in tissue of periparturient dairy cows. J. Dairy Sci. 78:2388-2394.

Grossman, A., G. M. Besser, J. J. Milles, and P. H. Baylis. 1980. Inhibition of vasopressin release in man by an opiate peptide. Lancet 2:1108-1110.
Horst, R. L., and T. A. Reinhardt. 1983. Vitamin D metabolism in ruminants and its relevance to the periparturient cow. J. Dairy Sci. 66:661-678.

Kim, O. M., G. H. Lim, and D. Y. Lim. 2005. Influence of naloxone on catecholamine release evoked by nicotinic receptor stimulation in the isolated rat adrenal gland. Arch. Pharm. Res. 28:699-708.

Lindsay, D. B., and D. W. Pethick. 1983. Adaptation of metabolism to various conditions: Metabolic Disorders. Pages 431-480 in Dynamic Biochemistry of Animal Production. A. NeimannSorensen and D. E. Tribe, ed. World Animal Science, Series A: Basic Information. Elsevier, New York, NY.

Mayerhofer, A., and S. Fritz. 2002. Ovarian acetylcholine and muscarinic receptors. Hints of a novel intrinsic regulatory system. Microsc. Res. Tech. 59:503-508.

McManaman, J. L., J. C. Blosser, and S. H. Appel. 1981. The effect of calcium on acetylcholine receptor synthesis. J. Neurosci. 1:771776.

Minoia, P., and R. L. Sciorsci. 2001. Metabolic control through L calcium channel, PKC and opioid receptors modulation by an association of naloxone and calcium salts. Curr. Drug Targets Immune Endocr. Metabol. Disord. 1:131-137.

Panerai, A. 1998. Glioppiacei. Pages 64-83in Neuropsicofarmacologia. R. Paoletti, S. Nicosia, F. Clementi, and G. Fumagalli, ed. UTET, Torino, Italy.

Petraglia, F., M. Baraldi, G. Giarrè, F. Facchinetti, M. Santi, A Volpe, and A. R. Genazzani. 1985. Opioid peptides of the pituitary and hypothalamus: Changes in pregnant and lactating rats. J. Endocrinol. 105:239-245.

Sansoè, G., and F. Wong. 2007. Natriuretic and aquaretic effects of intravenously infused calcium in preascitic human cirrhosis: Physiopathological and clinical implications. Gut 56:11171123.

Sciorsci, R. L., P. Bianchi, and P. Minoia. 2000. High levels of endorphin and related pathologies of veterinary concern. A review. Immunopharmacol. Immunotoxicol. 22:575-626.

Sciorsci, R. L., M. E. Dell'Aquila, and P. Minoia. 2001. Effects of naloxone on calcium turnover in cows affected by milk fever. J. Dairy Sci. 84:1627-1631.

Smilowitz, H., R. A. Hadjian, J. Dwyer, and M. B. Feinstein. 1981. Regulation of acetylcholine receptor phosphorylation by calcium and calmodulin. Proc. Natl. Acad. Sci. USA 78:4708-4712.

Sorensen, J. T., S. Ostergaard, H. Houe, and J. Hindhede. 2002. Expert opinions of strategies for milk fever control. Prev. Vet. Med. 55:69-78. 